\title{
Types of Logistics Outsourcing and Related Impact on the 3PL Buying Process: Empirical Evidence
}

\begin{abstract}
Although logistics outsourcing is recognised as a competitive parameter, so far there has been no adequate research on the types of logistics outsourcing and their implications in terms of the Third Party Logistics (3PL) buying process. This paper fills the gap by focussing on two key issues, i.e. required competitive advantages and 3PL selection criteria. The aim is to provide a comprehensive investigation of such factors and study if and how they vary depending on the outsourcing type. After a literature review and a focus group, a survey of 482 logistics managers was conducted, and a statistical analysis of results was performed. The findings are of interest to both shippers and 3PL providers because they help the former understand which outsourcing type is the most suitable to achieve the desired competitive advantages, and the latter to evaluate the key factors to focus on depending on the required type of outsourcing.
\end{abstract}

Keywords: Logistics Outsourcing, Third-Party Logistics (3PL) Providers, 3PL Buying Process, Competitive Advantages, 3PL Selection Criteria 


\section{Introduction}

Logistics outsourcing is currently a growing phenomenon and is becoming a strategic lever with a significant impact on shippers' business performance. The annual study conducted by Langley and Capgemini (2015) indicates that the overall market of logistics outsourcing services has increased by $30 \%$ since 2010 , generating revenue for more than 700 billion US\$. This rise could be explained by several factors. On the one hand, international competition and ongoing global recession have forced many companies to search for every possible means - logistics outsourcing included - to enhance their operational efficiency (Min, 2013). On the other hand, a rising demand for increased operating flexibility has been highlighted among shippers (e.g. Solakivi et al., 2013), driving them to look at logistics outsourcing as a possible means to face changes in demand and to meet the required service level. As a consequence, the interest in the topic of logistics outsourcing has grown over time, as shown by the increasing number of contributions in the literature (e.g. Marasco, 2008).

Overall, the buying process represents a crucial step for the success of an outsourcing initiative. The extant literature in this arena makes a distinction between the procurement of services and the procurement of products (e.g. Axelsson and Wynstra, 2002; Fitzsimmons et al., 1998; Wittreich, 1966). Indeed, peculiarities in services make them relatively difficult to standardise, count and value, which in turn implies that they entail greater performance ambiguity (Bowen and Jones, 1986).

The 3PL sourcing may be viewed as belonging to the 'service' category. A number of peculiarities related to the logistics services supply may be found, due to the uniqueness of each activity usually resulting from the high variability of tasks to meet customer-specific service requirements (e.g. Large et al., 2011; Yeung et al., 2006; Frediksson and Johansson, 2009; Vickery et al., 2004). Because of its specific features and requirements, a stream of dedicated literature has been developed on the 3PL buying process (e.g. Bandeira et al., 2015; 
Jharkharia and Shankar, 2007; Aghazadeh, 2003; Andersson and Norman, 2002; Sink and Langley 1997).

Although a number of contributions have been found in the extant literature, and different types of 3PL relationships have been recognised in the 3PL arena (e.g. Marchet et al., 2012; Knemeyer and Murphy, 2005; Skjoett Larsen, 2000), 3PL sourcing has been typically studied from a general perspective, without relating it to the type(s) of established outsourcing relationships. This represents a substantial gap, as shippers may either turn to a tactical partner for operational services or else consider a more integrative relationship (Coyle et al., 2009). Their willingness to enter a certain type of outsourcing relationship may imply different perspectives in terms of required 3PL competences, selection criteria and expected competitive advantages. Additionally, from a practical point of view, understanding the requirements and expectations of shippers is highly significant to 3PL providers in order to better evaluate the key factors to focus on when designing their offer, which allows them to improve their competitiveness on the market. Finally, although a high number of contributions may be found in the literature related to the 3PL buying process, there is still no shared vision on the key features of the 3PL buying process, nor on their perceived priority.

This paper aims to fill the above presented gaps by focussing on two key issues in the 3PL buying process as a whole, i.e. required competitive advantages and 3PL selection criteria. Specifically, the objective is twofold: firstly, to provide a comprehensive investigation of competitive advantages sought by shippers and 3PL selection criteria, including their prioritisation; secondly, to investigate whether such features vary depending on the type of established outsourcing relationship.

The rest of the paper is organised as follows. The next section summarises the literature review on competitive advantages sought by shippers and on 3PL selection criteria. Subsequently, the research background is presented, followed by the theoretical foundation 
and research questions. Section five illustrates the methodology, whereas the sixth section reports the main findings. Finally, conclusions are drawn and suggestions for future research are identified.

\section{Literature Review}

According to the main studies on the 3PL buying process (e.g. Aghazadeh, 2003; Sink and Langley, 1997), competitive advantages related to logistics outsourcing and 3PL selection criteria are key features in the 3PL buying process. These two main topics are discussed below.

\subsection{Competitive Advantages Related to Logistics Outsourcing}

It is widely accepted that major competences and focus on core business of 3PL providers are the main - and perhaps the most often mentioned - strategic reasons for outsourcing (Kremic et al., 2006). Overall, focussing on the expected benefits of logistics outsourcing five main required competitive advantages seem to emerge, and the identified elements are substantially homogeneous, as previously noted by Wilding and Juriado (2004). Table 1 summarises the main extant literature regarding the five competitive advantages related to logistics outsourcing [Table 1 near here].

First, cost reduction is considered one of the most important competitive advantages required from logistics outsourcing (e.g. Modarress et al., 2010; Jaafar and Rafiq, 2005; Bolumole, 2003; van Laarhoven et al., 2000). Indeed, according to Bolumole (2003), 3PL providers can offer advantages in terms of economy of scale to shippers, thanks to the increase in handled volumes achieved by working with other shippers. These economies of scale become apparent as handled volume increases without a proportionate increase in labour 
or equipment (i.e. operating costs). Another cost-related advantage lies in the reduction of invested capital, as 3PL providers offer shippers the opportunity to turn fixed costs into variable costs, as well as not locking unnecessary capital in costly logistics-related assets, facilities or equipment (e.g. Modarress et al., 2010; Selviaridis and Spring, 2007; Jaafar and Rafiq, 2005; Bolumole, 2003; Van Laarhoven et al., 2000; Sum and Teo, 1999).

Additionally, mainly in the fast moving consumer goods (FMCG) industry, there are other, more service-related, forces driving towards logistics outsourcing, such as flexibility increase (e.g. 'operational flexibility' as per Wilding and Juriado, 2004; 'strategic flexibility' as per Skjoett Larsen, 2000) and service level improvement, namely customer lead-time reduction and higher quality of service (e.g. Modarress et al., 2010; Selviaridis and Spring, 2007; Jaafar and Rafiq, 2005; Wilding and Juriado, 2004; Razzaque and Sheng, 1998).

In recent years, the need for shipper-oriented proactive improvements - in terms of process innovation, re-engineering of the logistics processes or access to latest technologies has finally begun to be considered as a possible competitive advantage related to logistics outsourcing. Indeed, according to Wallenburg et al. (2010) and Deepen et al. (2008), shipperoriented proactive improvements yield functional value to shippers in the form of efficiency and/or effectiveness enhancement. The authors state that shippers should achieve higher benefits (in terms of better performance) from a 3PL provider that displays proactive improvement in contrast to a non-proactive 3PL provider.

\subsection{PL Selection Criteria}

The topic of 3PL selection criteria has been widely studied (e.g. Marasco, 2008). In addition to some 'traditional' criteria, such as optimum cost and operational/delivery performance, other criteria have emerged as very important, such as reputation, cultural compatibility, financial stability or depth of management expertise/quality of management (Sink and 
Langley, 1997). In recent years, new criteria have also emerged, such as the ability to help shippers in case of emergency (e.g. ability of 3PL providers to cope with no standard variations in demand as per Jharkharia and Shankar, 2007). Moreover, non-logistics-focused criteria have been highlighted, such as the willingness of 3PL providers to retain a number of shippers' logistics employees - who would otherwise become unemployed after the outsourcing agreement - or convenient clause for arbitration and escape (Jharkharia and Shankar, 2007). Overall, there are some recurrent macro-criteria that scholars suggest to consider in the 3PL buying process. Specifically, 22 main 3PL selection criteria were identified, which for simplicity reasons are hereinafter listed depending on their main scope.

First, a cost-related criterion is widely acknowledged in the literature, i.e. cost of service (Perçin and Min, 2013; Qureshi et al., 2008; Jharkharia and Shankar, 2007; Arroyo et al., 2006; Bottani and Rizzi, 2006; Skjoett-Larsen, 2000; Razzaque and Sheng, 1998; Sink and Langley, 1997).

In addition to this cost factor, the 3PL providers' characteristics below - both distinctive features and reputation - may have an impact on the 3PL buying process:

- Size and quality of fixed assets (Qureshi et al., 2008; Jharkharia and Shankar, 2007; Bottani and Rizzi, 2006; Razzaque and Sheng, 1998);

- Provider certification (e.g. ISO9000, HACCP ) (Arroyo et al., 2006; Razzaque and Sheng, 1998);

- Market knowledge / Business experience (Perçin and Min, 2013; Perçin, 2009; Jharkharia and Shankar, 2007; Arroyo et al., 2006; Bottani and Rizzi, 2006; Razzaque and Sheng, 1998);

- High and improving standards (Arroyo et al., 2006; Razzaque and Sheng, 1998);

- Quality of management (Perçin and Min, 2013; Perçin, 2009; Qureshi et al., 2008; Jharkharia and Shankar, 2007; Skjoett-Larsen, 2000; Sink and Langley, 1997); 
- Reputation (Perçin and Min, 2013; Qureshi et al., 2008; Jharkharia and Shankar, 2007; Arroyo et al., 2006; Knemeyer and Murphy, 2005; Skjoett-Larsen, 2000; Razzaque and Sheng, 1998; Sink and Langley, 1997).

Additionally, four service-related criteria have emerged, namely:

- Geographical spread and broad range of service (Perçin and Min, 2013; Qureshi et al., 2008; Jharkharia and Shankar, 2007; Bottani and Rizzi, 2006; Arroyo et al., 2006; Skjoett Larsen, 2000; Razzaque and Sheng, 1998);

- Operational performance (Perçin and Min, 2013; Perçin, 2009; Qureshi et al., 2008; Jharkharia and Shankar, 2007; Bottani and Rizzi, 2006; Skjoett-Larsen, 2000; Razzaque and Sheng, 1998; Sink and Langley, 1997);

- Flexibility in operations and delivery (Perçin and Min, 2013; Qureshi et al., 2008; Jharkharia and Shankar, 2007; Arroyo et al., 2006; Bottani and Rizzi, 2006; Razzaque and Sheng, 1998; Sink and Langley, 1997).

With the technological progress characterising the last decade, the level of sophisticated IT solutions adopted - such as vehicle routing packages or carrier loading optimisation tools has become an important criterion, since the advanced IT capability of 3PL providers may help shippers reduce delivery uncertainties and inventory levels (Jharkharia and Shankar, 2007; Razzaque and Sheng, 1998). On this regard, two main IT-related criteria can be identified:

- Information technology capability (Perçin and Min, 2013; Qureshi et al., 2008; Jharkharia and Shankar, 2007; Arroyo et al., 2006; Bottani and Rizzi, 2006; Razzaque and Sheng, 1998; Sink and Langley, 1997);

- Tracking and tracing of the deliveries (Razzaque and Sheng, 1998).

Additional criteria may be acknowledged, related to the relationship between 3PL provider 
and shipper, namely:

- Prior relationship with the company (Arroyo et al., 2006);

- Long-term relationship (Perçin, 2009; Qureshi et al., 2008; Jharkharia and Shankar, 2007; Arroyo et al., 2006; Bottani and Rizzi, 2006; Razzaque and Sheng, 1998);

- Information sharing and trust (Qureshi et al., 2008; Jharkharia and Shankar, 2007; Bottani and Rizzi, 2006; Sink and Langley, 1997);

- Willingness to use shipper's logistics manpower (Jharkharia and Shankar, 2007);

- Employee satisfaction level (Jharkharia and Shankar, 2007; Razzaque and Sheng, 1998).

Finally, the following 3PL selection criteria related to risk management have emerged:

- Financial stability (Perçin and Min, 2013; Perçin, 2009; Qureshi et al., 2008; Jharkharia and Shankar, 2007; Arroyo et al., 2006; Bottani and Rizzi, 2006; Skjoett-Larsen, 2000; Razzaque and Sheng, 1998; Sink and Langley, 1997);

- Surge capacity (Jharkharia and Shankar, 2007; Qureshi et al., 2008);

- Clause for arbitration and escape (Jharkharia and Shankar, 2007);

- Flexibility in billing and payment (Jharkharia and Shankar, 2007; Sink and Langley, 1997).

\section{Research Background}

As anticipated, the interest in the topic of logistics outsourcing has grown over time and the contributions of experts in this field have increased in step, as highlighted by a comprehensive review of the 3PL literature conducted by Marasco (2008). Overall, the terms 'logistics outsourcing', '3PL', 'logistics alliances' and 'contract logistics' have generally been used in the literature to refer to the practice of outsourcing the execution of part or all of the logistics 
activities previously performed in house by a company.

In spite of this growing popularity, different specific definitions and interpretations of logistics outsourcing may be found. On the one hand, some of these appear to be quite broad, or 'inclusive', in nature - i.e. any logistics activity that is not performed 'in house' as being representative of 3PL, without distinctions between short-term and long-term considerations or between transactional and relational exchanges (e.g. Skjoett Larsen, 2000; Lieb, 1992). On the other hand, other definitions and interpretations have a more 'exclusive' nature, i.e. they focus on a long-term perspective, and emphasize that multiple activities can be provided (e.g. Murphy and Poist, 1998; Bagchi and Virum, 1996).

Table 2 contains some examples of 3PL definitions/interpretations, classified based on the nature of the relationship, i.e. 'inclusive' versus 'exclusive', as previously defined by Knemeyer and Murphy (2005) [Table 2 near here].

As highlighted by Table 2, the authors seem to take into account the same dimensions when expressing their definitions. Specifically, the authors mention: (i) the number of activities being outsourced, (ii) whether these activities are performed in an integrated or coordinated manner, and (iii) the involvement of the 3PL provider in planning/management activities. Furthermore, (iv) the duration of the relationship - to distinguish 3PL from traditional 'arm's length' sourcing - and (v) the mutual beneficial effects are often mentioned to define 3PL, especially when referring to the 'exclusive' interpretations mentioned above.

The duration and the mutual beneficial effects of the relationship are related to the type of 3PL provider involvement in planning/management activities, as previously emerged from the study by Makukha and Gray (2004). In their research the expert panel involved in the Delphi method agree that the involvement of 3PL providers at a strategic decision-making level must 
imply time-scale, sharing of commercial intentions, risks and rewards and commitment to financial investment.

Hence, a satisfactory classification of the available 3PL models seems to be related to two main key dimensions: (i) type of 3PL provider's involvement (i.e. execution versus planning) and (ii) outsourcing level (i.e. the extent to which the process is outsourced, in terms of number of activities outsourced and level of integration). With this rationale in mind, two main outsourcing models have been identified and adopted in the current study: (i) tactical outsourcing, i.e. decisions related to the outsourcing of the execution of traditional logistics activities, such as transportation or warehousing, to different 3PL providers; and (ii) strategic outsourcing, i.e. decisions related to the outsourcing of both planning and execution of the entire logistics process (or a large portion of it) to one 3PL provider (or a limited number of 3PL providers), as in Figure 1 [Figure 1 near here].

The tactical outsourcing model essentially implies that only the execution of the outsourced logistics activities is managed by 3PL providers, whereas the ownership of their planning and control is maintained internally. The shippers may have different 3PL providers, each of them selected based on the advantages that can be obtained (e.g. 3PL providers may be selected on the basis of their specialisation in terms of a single service, such as 'less than truck load'/'full truck load' shipments or geographic area covered). The length of outsourcing agreements is generally short (i.e. usually one year at the most). Conversely, the strategic outsourcing model implies that the entire logistics process is outsourced (or at least a large portion of it), and the make-or-buy decision occurs at a strategic level. The adoption of this model does not necessarily mean that the shipper loses the planning and control of all logistics activities completely but, rather, that there is a more strategic involvement of the 3PL provider at the 
planning/design level. Consistently with the different types of relationship, the length of outsourcing agreements is generally long (i.e. at least three years).

\section{Theoretical Foundation and Research Questions}

The literature review of earlier research on the 3PL buying process presented above reveals a number of gaps. First, although many authors have tackled competitive advantages and 3PL selection criteria when investigating logistics outsourcing, some significant limitations have been found. Secondly, a holistic view is missing, especially in terms of 3PL selection criteria, and no shared vision has been detected on the perceived priority assigned to the identified 3PL selection criteria. Thirdly, although the academic literature recognises that outsourcing decisions can vary in nature, to date the 3PL buying process and its related key factors (i.e. required competitive advantages and 3PL selection criteria) have been studied from a general perspective, without considering their relationship with the established type of outsourcing.

Previous studies on logistics outsourcing have provided a number of theoretical constructs, with the Transaction Cost Economics (TCE) or the Resource-Based Theory (RBT) being among the most widely adopted. Conversely, the use of other theories (e.g. Agency Theory or Network Theory) seems to be an exception rather than the rule (Selviaridis and Spring, 2007). The RBT, which was first introduced by Penrose (1959), states that a company can be viewed as a bundle of resources that are heterogeneously distributed across companies. Such differences allow companies to build a competitive advantage, for instance by having ownership of, or access to, a unique resource or innovation. The term 'resource' is broad in nature, as it refers not only to tangible assets, such as equipment, plants and location, but also to intangible assets, such as expertise, knowledge and organisational assets. The RBT supports logistics outsourcing suggests that the use of 3PL providers has enabled firms to gain access to complementary resources and create much more competitive resource bundles, 
providing them with a competitive advantage (Zacharia et al., 2011). This theoretical construct better reflects the objectives of the present study and has been adopted hereinafter.

According to the RBT, this paper aims to fill the identified gaps with a twofold objective. Firstly, it aims to provide a comprehensive investigation of the competitive advantages expected from logistics outsourcing (i.e. type of advantage(s) a shipper is looking for to maintain competitiveness in the marketplace) and the 3PL providers' selection criteria (i.e. specific resources that the shippers look for in a 3PL buying process to achieve a competitive advantage). Secondly, it aims to offer an in-depth understanding of how these features (i.e. competitive advantages required from logistics outsourcing and 3PL selection criteria) change depending on the type of logistics outsourcing sought by the shippers. Specifically, starting from these objectives, the following research questions were identified:

- RQ1: What are the main competitive advantages required from logistics outsourcing? Which is their priority order?

- RQ2: What are the main 3PL selection criteria based on the shipper's perspective? Which is their priority order?

- RQ3: Do the examined key decision factors (i.e. competitive advantages and 3PL selection criteria) vary depending on the type of logistics outsourcing (i.e. tactical versus strategic outsourcing)?

\section{Research Methodology}

The research methodology has been structured into 3 phases. In phase 1 a thorough review of the scientific literature was performed to identify the key factors in logistics outsourcing, and competitive advantages required from logistics outsourcing and 3PL selection criteria were specifically investigated. In this phase, secondary sources (e.g. practitioner studies) were also examined (e.g. Quinn and Hilmer, 1995). Information was collected by using a number of 
web databases, such as Scopus and Google Scholar. The analysis was based on papers, books and working papers and it covered the time period from 1989 to 2014 . The selected papers were primarily published in logistics journals (e.g. International Journal of Logistics Management, International Journal of Physical Distribution and Logistics Management, Journal of Business Logistics), although publications were also found in supply chain management (e.g. European Journal of Purchasing and Supply Management, Supply Chain Management: An International Journal), operation management (e.g. International Journal of Operations and Production Management) and marketing journals (e.g. Industrial Marketing Management). In order to search for topical contributions, a number of main keywords and strings were identified, such as 'logistics outsourcing', '3PL', 'buying process', 'competitive advantage', and 'selection criteria' that were to be found in both the abstract and the main body of the paper. We also went back to other papers by cross-referencing, thus including potential papers that had not been taken into account yet. The entire analysis eventually led to the identification of 43 papers that, according to the authors, have provided useful insights into the analysed topic.

In phase 2 (i.e. collection of experts' opinions) the results of the literature review were presented to a focus group (i.e. qualitative group discussions with senior level supply chain management professionals) to collect feedback and recommendations for improving the research framework and restrict the research area. The group was assembled and participants were selected relying on the activity of the Observatory of Contract Logistics, a permanent research initiative - now in its fifth year of activity - launched by Politecnico di Milano School of Management on the themes of logistics outsourcing, involving over 40 companies (both shippers and 3PL providers). Specifically, the focus group involved 16 leading Italian shippers in a single in-depth discussion that lasted approximately 2 hours.

Based on that, the following competitive advantages were considered in this study: (i) 
operating cost reduction, (ii) invested capital reduction, (iii) flexibility increase, (iv) customer service level improvement, (v) innovation capability improvement and (vi) risk reduction linked to the development of knowledge and new technologies. This last factor emerged from practitioner studies (e.g. Quinn and Hilmer, 1995) and was then confirmed as significant by the focus group.

With regard to the 3PL selection criteria, the focus group carefully examined the list of items emerged from the literature review, and confirmed all of them with the exception of 'cost of service' and the 3PL provider's 'prior relationship with the company', as both of them were considered strictly related to the specific relationship and therefore more difficult to generalise in relation to the type of outsourcing. Additionally, based on the logistics managers' feedback, (i) attention to environmental sustainability, (ii) investment capacity, (iii) level of control of sub-contractors and (iv) service level customisation were also included in the analysis. This phase ultimately led to a list of 24 items to be taken into account, as shown in Table 3.

Phase 3 involved an exploratory study (i.e. survey-based) targeting Italian companies. Survey research allows to statistically assess the attitudes and characteristics of relatively large external samples (Wacker, 1998). In particular, given the early stages of this research into the examined phenomenon, an exploratory survey was selected as the suitable methodology, aiming to gain preliminary insight on the topic and then provide the basis for more in-depth studies (Forza, 2002; Pinsonneault and Kraemer, 1993).

A six-page questionnaire was developed, structured into 4 main sections. Section 1 contained questions related to general information about the survey respondents (i.e. contact details, job title, industry and annual revenue of the company). Section 2 was devoted to investigating the main type of outsourcing relationship. Respondents were asked to declare the outsourcing level of their activities (i.e. tactical or strategic versus internally managed). Finally, sections 3 
and 4 investigated the competitive advantages related to logistics outsourcing and 3PL selection criteria, respectively. As far as the competitive advantages are concerned, respondents were asked to assign a percentage from 0 to $100 \%$ depending on the importance assigned to each. Looking at the key selection criteria in the 3PL evaluation, respondents were asked to indicate the ten (out of 24) 3PL selection criteria deemed as most important on a scale of 1 to $10(1=$ most important, $10=$ least important $)$. Each item was accompanied by a brief description in order to avoid misunderstandings (e.g. investment capacity: willingness and financial means of 3PL providers to invest in warehouse automation or other capitalintensive solutions).

The questionnaire structure and content was discussed with the focus group and pre-tested with a representative group of companies before being sent via mail. A cover letter accompanied the questionnaire form explaining the aim of the study. Three main sources were used to build the sampling frame in the Italian market: (i) the database of the above-mentioned Observatory on Contract Logistics, (ii) trade publications, and (iii) web sources.

The questionnaire was finally mailed to seniors and middle managers of 482 companies operating in Italy. In total, 107 usable responses were received, with a response rate of $22 \%$. According to Malhotra and Grover (1998), response rates over 20\% are considered as satisfactory for mail surveys. Note that 17 of the responding companies (16\%) declared to manage their logistics activities mainly internally. For the scope of our analysis, these companies were excluded from our analysis, and therefore the total sample size for the data analysis was reduced to 90 companies. Among these 90 companies, 47 declared to adopt mainly a tactical outsourcing approach, while the remaining 43 mainly a strategic one. Looking at the examined sample (i.e. 90 companies), the majority of respondents (i.e. $82 \%$ ) were Logistics or Supply Chain Directors and about $60 \%$ declared to operate in one among 
the Fashion, Food, Retail or Pharmaceutical industries. 40\% of respondents reported annual sales exceeding $€ 500$ million, whereas $34 \%$ declared an annual sale volume between $€ 100$ and $€ 500$ million. Only $8 \%$ of respondents presented annual sales lower than $€ 50$ million. The potential for selection bias was tested by comparing early respondents (the first 30 ) to late respondents (the last 30) for each company characteristics (i.e. industry type and annual sales) and surveyed items (i.e. competitive advantages and 3PL selection criteria) using ANOVA (Wagner and Kemmerling, 2010; Armstrong and Overton, 1977). The results showed that at the 0.05 level there were no significant differences between the mean scores of early and late respondents in terms of characteristics and surveyed items in both samples, thus confirming that there is no evidence of non-response bias.

Due to the limitations of this type of non-response bias test, we also compared our sample characteristics to our sampling frame to provide support for the representativeness of the respondents' sample and therefore allow the generalisation of results (Nix and Zacharia, 2014). The industry distribution for respondents is similar to the total sample industry distribution. About $70 \%$ of respondents are from one among the fashion, food, electrics/electronics, retail and pharmaceutical industries. The distribution of non-respondents per industry is also similar to the distribution of the total sample size. In the sample of respondents, the mechanical engineering sector is not represented. Based on our analysis, it emerged that none of the other industries presented a significantly different distribution from the one of the sample partitioning. As far as the annual sales are concerned, it is necessary to highlight that only $8 \%$ of respondents presented annual sales lower than $€ 50$ million: this percentage is lower compared to the composition of the Italian industrial structure, which means SMEs were less represented. Therefore, the generalisation of our results must take into account this consideration.

Finally, a statistical analysis of the results was carried out. Statistical tests were performed on 
each examined competitive advantage and on selection criteria to evaluate their variation depending on the type of outsourcing (i.e. tactical outsourcing versus strategic outsourcing). Before using the Independent T-Test, a preliminary test for normality (Skewness-Kurtosis tests) was performed. Since the majority of data did not meet the assumptions for using the TTest, a non-parametric test was used for our analysis. In particular, the Mann-Whitney U test was performed to compare the central tendency (median) of two independent samples (Tysseland, 2009; Williams and Tokar, 2008). Data analysis was processed using STATA 12.1 for Windows.

\section{Findings and Discussion}

\subsection{Competitive Advantages Related to Logistics Outsourcing}

According to the survey responses [Table 3 near here], the first two competitive advantages indicated as being the most important are operating cost reduction and flexibility increase, with an average importance of $28.6 \%$, followed by invested capital reduction.

This evidence confirms that logistics outsourcing is primarily viewed as a means to reduce costs and increase flexibility. Indeed, 3PL providers can offer cost advantages to companies because they provide them with the opportunity to not tie unnecessary capital in costly logistics-related equipment (e.g. warehouses or trucks) and they also provide economies of scale (e.g. Bolumole, 2003).

As far as the type of outsourcing is concerned (i.e. tactical versus strategic), it is interesting to note that, although the prioritisation of the competitive advantages does not vary between the two samples, several differences emerge looking at the weight assigned to each. 
Indeed, companies adopting a tactical outsourcing approach seem to give more importance after cost factors - to flexibility increase, since they want to take advantage of the 3PL providers' ability to cope with variations in demand, giving less importance to improvement in customer service level and improvement in innovation capability. Risk reduction has a negligible weight for both outsourcing types.

Looking at the significance of these differences, Table 3 shows the p-values (last column, numbers in bold) under which the null hypothesis (stating that the central tendencies in the two samples are equal) is rejected, with a significance level of 5\%. Flexibility increase, improvement of customer service level and improvement of innovation capability appear to be the only three significantly different factors from a statistical point of view. In particular, while flexibility increase is deemed as among the most important by companies outsourcing their logistics activities with a tactical approach, the other two factors are mainly related to a strategic perspective.

Finally, the survey reveals that both tactical and strategic samples consider operating cost reduction as the most important advantage required from logistics outsourcing. This evidence, read under the lens of the motivational theory by Herzberg, shows that companies seem to consider operating cost reduction as a 'cross key factor', i.e. a sort of 'hygiene factor' (Herzberg, 1964) in order to enter an outsourcing relationship, whose absence may lead to dissatisfaction, but whose presence does not necessarily lead to satisfaction and is not necessary related to a certain outsourcing approach.

\subsection{PL Selection Criteria}

As highlighted above, the focus group pointed out four additional criteria that were not mentioned in the scientific literature, i.e. investment capacity, service level customisation, control level of sub-contractors and attention to environmental sustainability. The survey 
results confirmed the significance of these criteria, with a different priority order. Specifically, investment capacity (i.e. willingness and financial means of 3PL providers to invest in warehouse automation or other capital-intensive solutions) was found to be the second most important selection criteria, with an average importance of 4.3 , which is rather similar for both outsourcing approaches. Such evidence demonstrates that increasing attention among shippers towards two main issues that investment capacity implies, i.e. logistics process innovation and risk management. On the one hand, shippers may view 3PL's investment capacity as an opportunity to obtain a higher level of innovation in their logistics processes. On the other hand, from a risk management perspective, 3PL's investment capacity also involves a certain level of 'stability' and mitigates the shippers' perceived risk related to the management of their logistics processes also in presence of volume volatility. Moreover, as previously remarked by Large (2007), the 3PL providers' specific investments towards a particular shipper have a positive impact on the performance and the satisfaction level perceived by such shipper.

As far as the other three criteria are concerned, service level customisation and control level of sub-contractors are placed in intermediate ranking positions, whereas attention to environmental sustainability was considered as the least important. This evidence seems interesting since it allows to underline a possible mismatch between the growing attention declared by companies towards environmental issues - especially as far as road transportation is concerned - and the criteria they actually look at to choose their logistics partner. Looking at the overall survey results [Table 4 near here], the foremost selection criteria emerged from the empirical study are flexibility in operations and delivery (with an average importance of 4.1), followed by investment capacity and operational performance. 
Reputation, clause for arbitration and escape and willingness to use shipper's logistics manpower have been considered as the less important criteria.

The emphasis given to 3PL selection criteria seems to be different depending on the company approach to outsourcing, and it is interesting to note how the prioritisation varies between the two samples. Indeed, the 'top four' criteria judged as most important by the companies adopting a tactical outsourcing approach are investment capacity, operational performance, flexibility in operations and delivery and surge capability. Instead, for those companies primarily adopting a strategic outsourcing approach, the selection criteria priority order is completely different: the most important seems to be the knowledge of the industry in which the shipper operates, followed by flexibility in operations and delivery, geographical spread and size and quality of fixed assets. Except from flexibility in operations and delivery - which appears among the 'top four' for both tactical and strategic outsourcing approaches the differences in the priority of the 3PL selection criteria confirm that the focus shifts from operational drivers (i.e. in the tactical approach) to more strategic considerations (i.e. strategic approach).

'Flexibility in operations and delivery' has emerged as a cross key criterion for both outsourcing approaches (i.e. in $25 \%$ of cases it is declared as the most important in both samples). This shows that the 3PL providers' ability to offer tailored services (e.g. in terms of delivery time, place and form) to meet shippers' changing requirements seems now to be considered a 'must have' service by shippers, regardless of the type of outsourcing they are looking at.

The results of the Mann Whitney U Test show that four criteria (i.e. geographical spread, size and quality of fixed assets, information sharing and trust and reputation) present a statistically significant difference in terms of average importance given to 3PL selection criteria from a tactical or strategic outsourcing approach. These criteria are more important for those 
companies that adopt a strategic outsourcing approach. Table 3 also shows the p-values (last column, numbers in bold) under which the null hypothesis (stating that the central tendencies in the two samples are equal) is rejected, with a significance level of 5\%.

These results confirm that, from a statistical point of view as well, the focus seems to shift from operational drivers to more strategic considerations. Based on the results achieved, the distinctive 3PL selection criteria identified by shippers in order to build a strategic outsourcing relationship are as follows:

- geographical spread offered by the 3PL provider, which is desirable in order to reach all of the markets (or a large portion of them) served by the shippers, as observed by Skjoett Larsen (2000) as well;

- reputation, since brand name endorses quality, reliability, customer service level, customer satisfaction and contract fulfilment. The reputation of the 3PL providers also guarantees a sound financial position to begin a long-term relationship (Jharkharia and Shankar, 2007);

- information sharing and trust, which means a high level of mutual trust between shipper and 3PL provider, with interaction and data sharing, which is one of the most important elements making long-term partnerships possible, as per Bottani and Rizzi (2006);

- $\quad$ size and quality of fixed assets, i.e. the availability of appropriate physical equipment (such as air-conditioned warehouses and low-consumption vehicles) offered by the 3PL provider and that suit the shipper's need.

In the recent literature (e.g. Zolfagharinia and Haugton, 2012; Rajesh et al., 2011) information sharing and trust have been progressively recognised as key factors for a successful relationship. Indeed, interaction and relationship experience are acknowledged as distinctive features driving 3PL providers to utilise the acquired knowledge to design and implement 
innovative solutions and solutions tailored to the shipper (Yazdanparast et al., 2010). Furthermore, as per Mellat-Parast and Spillan (2014) and Nix and Zacharia (2014), logistics process integration and collaboration practices, such as coordinated and shared planning, are strongly related to the shippers' competitiveness. This perspective has been also supported by the Knowledge Based View (KBV), a subcategory of the very well-known RBV that considers inter-company linkage and processes as one of the most important strategic resources for competition (e.g. Lai et al., 2012; Dyer and Singh, 1998).

\section{Conclusions}

This paper presents the results of a survey-based study on the 3PL buying process, focussing on its key factors (i.e. competitive advantages and 3PL selection criteria) and their relationship with the type of established outsourcing (i.e. tactical versus strategic). Looking at RQ1 (i.e. What are the main competitive advantages required from logistics outsourcing? Which is their priority order?) and RQ2 (i.e. What are the main 3PL selection criteria based on the shipper's perspective? Which is their priority order?), this study offers a clear and comprehensive classification of six competitive advantages required by shippers from logistics outsourcing and 24 3PL selection criteria considered in a 3PL buying process. The overall results provided are particularly valuable as the logistics managers' perspective is also included thanks to the information gathered during the focus group. In particular, it is worth noting that the 3PL selection criteria suggested by the logistics managers address innovation, risk management and sustainability, which are currently hot topics in the broader supply chain research.

Looking at the priority of the competitive advantages, the survey findings reveal that the most important are related to operating cost reduction and flexibility increase, in line with 
the literature, whereas the foremost 3PL selection criteria that emerged are flexibility in operations and delivery, investment capacity and operational performance. In particular, our study highlights the importance of investment capacity as a 3PL selection criterion (i.e. it is the second most important selection criteria emerged), which was not mentioned in the previous literature, but instead was suggested by the focus group. Conversely, according to the survey results, sustainability - although identified by the focus group as among the key 3PL selection criteria to be included - was found to be not very important.

As far as RQ3 is concerned (i.e. Do the examined key decision factors - i.e. competitive advantages and 3PL selection criteria - vary depending on the type of logistics outsourcing?), the study reveals that, although the prioritisation of the competitive advantages does not vary between the two samples, several differences emerge looking at the weight assigned to each. Indeed, besides cost advantages, which could be considered a 'cross key factor' in order to enter a 3PL relationship, in the case of strategic outsourcing the desired improvements mainly refer to customer service level and innovation capability, whereas, in the case of tactical outsourcing, to flexibility increase.

Looking at the 3PL selection criteria, differences in the prioritisation between the two samples confirm that the focus shifts from operational drivers (i.e. in the tactical approach) to more strategic considerations (i.e. strategic approach). Nevertheless, the survey results underline the importance of 'flexibility in operations and delivery' as a cross key criterion between the two outsourcing approaches, showing that the extent to which 3PL providers tailor services according to shipper's changing needs is considered more and more by shippers as a 'must have' service (and no longer as a 'value added' service). Finally, our research highlights statistically significant differences between companies outsourcing their logistics activities in a strategic perspective and those adopting a tactical approach. Specifically, with regard to competitive advantages related to logistics outsourcing, 
the importance assigned to customer service level improvement and innovation capabilities is statistically higher for the companies adopting a strategic outsourcing approach. Similarly, the 3PL selection criteria with a statistically higher average importance for companies with a strategic outsourcing approach are geographical spread, size and quality of fixed assets, reputation and information sharing and trust. These findings seem to confirm that shippers' requirements vary depending on the type of outsourcing they are interested in.

From a managerial perspective, the results of this study are firstly useful to help shippers understand the most suitable type of logistics outsourcing to undertake for achieving the desired competitive advantage(s). Results also support shippers by suggesting the most important selection criteria to be adopted when assessing 3PL providers.

Secondly, this study may also offer a valuable perspective to help 3PL managers better evaluate the key factors they should focus on to design their own offer (i.e. referring to the 3PL selection criteria that emerged as most important), also taking into account the type of outsourcing relationship they are entering.

This study presents limitations that should be taken into account. Firstly, the empirical research was limited to Italian companies. This limitation does not allow to understand if shippers operating in different countries approach the 3PL buying process differently, and therefore if there are any country-related features affecting such process (e.g. policy or cultural perspectives, 3PL providers' characteristics). Secondly, although this study represents an important picture of the current state of the market, it does not show if and how the key factors in the 3PL buying process, as well as their prioritisation, may vary over time. Although the generalisation of our results must take these considerations into account, this study represents a first step towards a new investigation area that has not been studied in depth yet (i.e. relationship between required competitive advantages/3PL selection criteria 
and logistics outsourcing type, i.e. tactical versus strategic), with a strong impact both for academics and practitioners, as illustrated above.

Building upon the results of our study, further research may go towards an additional analysis of the examined logistics outsourcing models (i.e. tactical versus strategic outsourcing). For instance, a deeper investigation of the perceived disadvantages related to logistics outsourcing may be recommended, starting for example from Kremic et al. (2006) or Razzaque and Sheng (1998). Specifically, it would be interesting studying whether and how the perceived disadvantages related to logistics outsourcing may vary depending on the logistics outsourcing model sought after by shippers. Finally, the study presented in this paper paves the way for future research from the 3PL providers' perspective. To this extent, further investigation may be beneficial on the strategies 3PL providers should focus on in order to create value for shippers. 


\section{References}

Aghazadeh, S.-M. (2003) 'How to Choose an Effective Third Party Logistics Provider', Management Research News, Vol. 26 No. 7, pp. 50 - 58.

Andersson, D., and Norrman, A. (2002) 'Procurement of Logistics Services - A Minutes Work or a Multi-year Project?', European Journal of Purchasing and Supply Management, Vol. 8 No. 1, pp. 3 - 14.

Arroyo, P., Gaytan, J. and de Boer, L. (2006) 'A Survey of Third Party Logistics in Mexico and a Comparison with Reports on Europe and USA', International Journal of Operations and Production Management, Vol. 26 No. 6, pp. 639 - 667.

Armstrong, J. Scott, and Overton, Terry S. (1977) 'Estimating Nonresponse Bias in Mail Surveys', Journal of Marketing Research, Vol. 14 No. 3, pp. 396 - 402.

Axelsson, B. and Wynstra, F. (2002) Buying Business Services, Wiley, Chichester.

Bandeira, R. A. de Mello, Maçada, A. C. G. and De Brito Mello, L. C. B. (2015) 'Logistics outsourcing: the decision-making process in contracting companies', International Journal of Logistics Systems and Management, Vol. 21 No. 1, pp. 92 - 114.

Berglund, M., van Laarhoven, P., Sharman, G. and Wandel, S. (1999) 'Third-Party Logistics: Is There a Future?', International Journal of Logistics Management, Vol. 10 No. 1, pp. $59-70$.

Bagchi, P. K., and Virum, H. (1996) 'European Logistics Alliances: A Management Model', International Journal of Logistics Management, Vol. 7 No. 1, pp. 93 - 108.

Bolumole, Y. A. (2003) 'Evaluating the Supply Chain Role of Logistics Service Providers', International Journal of Logistics Management, Vol. 14 No. 2, pp. 93 - 107.

Bottani, E. and Rizzi, A. (2006) 'A Fuzzy TOPSIS Methodology to Support Outsourcing of Logistics Services', Supply Chain Management: An International Journal, Vol. 11 No. 4, pp. 294 - 308.

Bowen, D. E. and Jones, G. R. (1986) 'Transaction Cost Analysis of Service OrganizationCustomer Exchange', Academy of Management Review Vol. 11 No. 2, pp. 428 - 441.

Coyle, J. J., Langley, C. J., Gibson, B. J., Novack, R. A. and Bardi, E. J. (2009) Supply Chain Management: A Logistics Perspective, $8^{\text {th }}$ edition. South-Western Cengage Learning, Mason.

Deepen, J. M., Goldsby, T. J., Knemeyer, A. M. and Wallenburg, C. M. (2008) 'Beyond Expectations: An Examination of Logistics Outsourcing Goal Achievement and Goal Exceedance', Journal of Business Logistics, Vol. 29 No. 2, pp. 75 - 105. 
Dyer, J. H. and Singh, H. (1998) 'The Relational View; Cooperative Strategy and Sources of Interorganizational Competitive Advantage', The Academy of Management Review Vo. 23 No. 4, pp. 660 - 679.

Fitzsimmons, J. A., Noh, J. and Thies, E. (1998) 'Purchasing Business Services', Journal of Business and Industrial Marketing, Vol. 13 No. 4/5, pp. 370 - 380.

Forza, C. (2002) 'Survey Research in Operations Management: A Process-based Perspective', International Journal of Operations and Production Management, Vol. 22 No. 2, pp. 152 - 194.

Frediksson, A. and Johansson, E. (2009) 'Integrating Logistics into the Outsourcing Process' International Journal of Logistics: Research and Applications, Vol. 12 No. 4, pp. 281 - 298.

Herzberg, F. (1964) 'The Motivation-Hygiene Concept and Problems of Manpower', Personnel Administration, Vol. 27 No. 1, pp. 3 - 7.

van Laarhoven, P., Berglund, M. and Peters, M. (2000) 'Third-Party Logistics in Europe Five Years Later' International Journal of Physical Distribution and Logistics Management, Vol. 30 No. 5, pp. 425 - 442.

Lai, F., Zhang, M., Lee, D. M. S. and Zhao, X. (2012) 'The Impact of Supply Chain Integration on Mass Customization Capability: An Extended Resource-Based View', IEEE Transactions on Engineering Management, Vol. 59 No. 3, pp. 443 - 465.

Large, R. O. (2007) 'The Influence of Customer-specific Adaptation on the Performance of Third-Party-Logistics Relationship - Document Studies and Propositions', International Journal of Logistics: Research and Applications, Vol. 10 No. 2, pp. 123 - 133.

Large, R. O., Kramer, N. and Hartmann, R. K. (2011) 'Customer-specific Adaptation by Providers and their Perception of 3PL-Relationship Success', International Journal of Physical Distribution and Logistics Management, Vol. 41 No. 9, pp. 822 - 838.

Langley, C. J. and Capgemini (2015) '2013 Third-Party Logistics Study: The State of Logistics Outsourcing. Results and Findings of the 19th Annual Study' available at: http://www.3plstudy.com/ (accessed 7 July 2015).

Lieb, R. C. (1992) 'The Use of Third-Party Logistics Services by Large American Manufacturers' Journal of Business Logistics, Vol. 13 No. 2, pp. 29 - 42. 
Jaafar, H. S. and Rafiq, M. (2005) 'Logistics Outsourcing Practices in the UK: A Survey', International Journal of Logistics: Research and Applications, Vol. 8 No. 4, pp. 299 312.

Jharkharia, S., and Shankar, R. (2007) 'Selection of Logistics Service Provider: An Analytic Network Process (ANP) Approach', International Journal of Management Science, Vol. 35, pp. 274 - 289.

Kremic, T., Tukel, O. I. and Rom, W. O. (2006) 'Outsourcing Decision Support: A Survey of Benefits, Risks, and Decision Factors', Supply Chain Management: An International Journal, Vol. 11 No. 6, pp. 467 - 482.

Knemeyer, A. M. and Murphy, P. R. (2005) 'Is the Glass Half Full or Half Empty? An Examination of Users and Provider Perspectives towards Third-Party Logistics Relationships', International Journal of Physical Distribution and Logistics Management, Vol. 35 No. 10, pp. 708 - 727.

Malhotra, M. K. and Grover, V. (1998) 'An Assessment of Survey Research in POM: from Constructs to Theory', Journal of Operations Management Vol. 16 No. 17, pp. 407 25.

Makukha, K. and Gray, R. (2004) 'Logistics Partnerships between Shippers and Logistics Service Providers: The Relevance of Strategy', International Journal of Logistics: Research and Applications, Vol. 7 No. 4, pp. 361 - 377.

Marasco, A. (2008) 'Third-Party Logistics: A Literature Review', International Journal of Production Economics, Vol. 113 No. 1, pp. 127 - 147.

Marchet, G., Perego, A., Melacini, M., Perotti, S. and Tappia. E. (2012) 'Logistics Outsourcing in the Italian Fashion Industry: an empirical study', Paper presented at the International Workshop on luxury retail, operations and Supply Chain management, Milano, December 3-4.

Mellat-Parast, M. and Spillan, J. E. (2014) 'Logistics and Supply Chain Process Integration as a Source of Competitive Advantage: An Empirical Analysis', International Journal of Logistics Management Vol. 25 No. 2, pp. 289 - 314.

Min, H. (2013) 'Examining Logistics Outsourcing Practices in the United States: from the Perspectives of Third-Party Logistics Service Users', Logistics Research, Vol. 6 No. 4, pp. $133-144$. 
Modarress, B., Ansari, A. and Lockwood, D. (2010) 'Outsourcing logistics to third-party providers: practitioners perspectives', International Journal of Logistics Systems and Management, Vol. 6 No. 1, pp. $23-38$.

Murphy, P. R. and Poist, R. F. (1998) 'Third-Party Logistics Usage: An Assessment of Propositions Based on Previous Research', Transportation Journal, Vol. 37 No. 4, pp. $26-35$.

Nix, N. W. and Zacharia, Z. G. (2014) 'The Impact of Collaborative Engagement on Knowledge and Performance Gains in Episodic Collaborations', International Journal of Logistics Management, Vol. 25 No. 2, pp. 245 - 269.

Penrose, E. T. (1959) The Theory of the Growth of the Firm, Wiley, New York.

Perçin, S. (2009) 'Evaluation of Third-Party Logistics (3PL) Providers by Using a Two-Phase AHP and TOPSIS Methodology', Benchmarking: An International Journal, Vol. 16 No. 5 , pp. 588 - 604 .

Perçin, S. and Min, H. (2013) 'A Hybrid Quality Function Deployment and Fuzzy DecisionMaking Methodology for the Optimal Selection of Third-Party Logistics Service Providers', International Journal of Logistics: Research and Applications, Vol. 16 No. 5 , pp. $380-397$.

Pinsonneault, A. and Kraemer, K. L. (1993) 'Survey Research Methodology in Management Information Systems: An Assessment', Journal of Management Information Systems, Vol. 10 No. 2, pp. 75 - 106

Quinn, J. B. and Hilmer, F. G. (1995) 'Strategic Outsourcing. By Assessing the Relative Costs and Risks of Making or Buying, Companies Can Leverage their Skills and Resources for Increased Profitability', The McKinsey Quarterly, Vol. 1, pp. 48 - 70.

Qureshi, M. N., Kumar, D. and Kumar, P. (2008) 'An Integrated Model to Identify and Classify the Key Criteria and their Role in the Assessment of 3PL Services Providers', Asia Pacific Journal of Marketing and Logistics, Vol. 20 No. 2, pp. 227 - 249.

Rajesh, R., Pugazhendhi, S., Ganesh, K., Ducq Yves, Lenny Koh, S. C. and Muralidharan, C. (2011) 'Perceptions of Service Providers and Customers of Key Success Factors of Third Party Logistics Relationship - An Empirical Study', International Journal of Logistics: Research and Applications, Vol. 14 No. 4, pp. 211 - 250.

Razzaque, M. A. and Sheng, C. C. (1998) 'Outsourcing of Logistics Functions: A Literature Survey', International Journal of Physical Distribution and Logistics Management, Vol. 28 No. 2, pp. 89 - 107. 
Selviaridis, K. and Spring, M. (2007) 'Third Party Logistics: A Literature Review and Research Agenda', International Journal of Logistics Management, Vol. 18 No. 1, pp. $125-150$.

Sink, H. L. and Langley, C. J. (1997) 'A Managerial Framework for the Acquisition of ThirdParty Logistics Services', Journal of Business Logistics, Vol. 18 No. 2, pp. 163 - 189.

Skjoett-Larsen, T. (2000) 'Third Party Logistics - from an Interorganizational Point of View', International Journal of Physical Distribution and Logistics Management, Vol. 30 No. 2, pp. 112 - 127.

Solakivi, T., Töyli, J. and Ojala, L. (2013) 'Logistics Outsourcing, its Motives and the Level of Logistics Costs in Manufacturing and Trading Companies Operating in Finland', Production Planning and Control: The Management of Operations, Vol. 24 No. 4/5, pp. $388-398$.

Sum, C.-C., and Teo, C.-B. (1999) 'Strategic Posture of Logistics Service Providers in Singapore', International Journal of Physical Distribution and Logistics Management, Vol. 29 No. 9, pp. 588 - 605.

Tysseland, B. E. (2009) 'Spare Parts Optimization Process and Results’, International Journal of Physical Distribution and Logistics Management, Vol. 39 No. 1, pp. 8 - 27.

Vickery, S. K., Droge, C., Stank, T. P., Goldsby, T. J. and Markland, R. E. (2004) 'The Performance Implication of Media Richness in a Business-to-Business Service Environment: Direct Versus Indirect Effects', Management Science, Vol. 50 No. 8, pp. $1106-1119$.

Wacker, J. G. (1998) 'A Definition of Theory: Research Guidelines for Different TheoryBuilding Research Methods in Operations Management', Journal of Operations Management, Vol. 16 No. 4, pp. 361 - 385.

Wagner, S. M. and Kemmerling, R. (2010) 'Handling Nonresponse in Logistics Research', Journal of Business Logistics, Vol. 31 No. 2, pp. 357 - 381.

Wallenburg, C. M., Knemeyer, A. M., Goldsby, T. J. and Cahill, D. L. (2010) 'Developing a Scale for Proactive Improvement within Logistics Outsourcing Relationship', International Journal of Logistics Management Vol. 21 No. 1, pp. 5 - 21.

Wilding, R. and Juriado, R. (2004) 'Customer Perceptions on Logistics Outsourcing in the European Consumer Goods Industry', International Journal of Physical Distribution and Logistics Management, Vol. 34 No. 8, pp. 628 - 644. 
Williams, B. D. and Tokar, T. (2008) 'A review of Inventory Management Research in Major Logistics Journals', International Journal of Logistics Management, Vol. 19 No. 2, pp. $212-232$.

Wittreich, W. J. (1966) 'How to Buy/Sell Professional Services', Harvard Business Review, Vol. 44 No. 2, pp. 127 - 138.

Yazdanparast, A., Manuj, I. and Swartz, S. M. (2010) 'Co-creating Logistics Value: A Service-Dominant Logic Perspective', International Journal of Logistics Management, Vol. 21 No. 3, pp. 375 - 403.

Yeung, J. H. Y., Selen, W., Sum, C.-C. and Huo, B. (2006) 'Linking Financial Performance to Strategic Orientation and Operational Priorities: An Empirical Study of Third-Party Logistics Providers', International Journal of Physical Distribution and Logistics Management, Vol. 36 No. 3, pp. 210 - 230.

Zacharia, Z. G., Sanders, N. R. and Nix, N. W. (2011) 'The Emerging Role of the Third Party Logistics Provider (3PL) as an Orchestrator', Journal of Business Logistics. Vol. 32 No. 1, pp. 40 - 54.

Zolfagharinia, H. and Haugton, M. A. (2012) 'The benefit of information sharing in a logistics outsourcing context', International Journal of Logistics Systems and Management, Vol. 13 No. 2 pp. 187 - 208. 
Main competitive advantages

required from logistics outsourcing

Modarress et al., 2010; Selviaridis and Spring, 2007;

Arroyo et al., 2006; Kremic et al., 2006; Jaafar and Rafiq,

Operating cost reduction

2005; Wilding and Juriado, 2004; Bolumole, 2003; van

Laarhoven et al., 2000; Skjoett-Larsen, 2000; Razzaque

and Sheng, 1998.

Modarress et al., 2010; Selviaridis and Spring, 2007;

Invested capital reduction

Kremic et al., 2006; Jaafar and Rafiq, 2005; Bolumole,

2003; van Laarhoven et al., 2000; Sum and Teo, 1999.

Selviaridis and Spring, 2007; Arroyo et al., 2006; Kremic

Flexibility increase

et al., 2006; Jaafar and Rafiq, 2005; Wilding and Juriado,

2004; Skjoett-Larsen, 2000.

Modarress et al., 2010; Selviaridis and Spring, 2007;

Arroyo et al., 2006; Kremic et al., 2006; Jaafar and Rafiq,

Customer service level improvement

2005; Wilding and Juriado, 2004; van Laarhoven et al.,

2000; Skjoett-Larsen, 2000; Sum and Teo, 1999;

Razzaque and Sheng, 1998.

Innovation capability improvement

Wallenburg et al., 2010; Deepen et al., 2008; Arroyo et

al., 2006; Kremic et al., 2006.

Table 1. Main competitive advantages required from logistics outsourcing. 
3PL entails both "tactical decisions about outsourcing the execution of traditional logistics activities, such as transportation or warehousing, to different 3PL providers and strategic decisions about outsourcing the whole logistics process (or a large part of it)"

Marchet et al.

$(2012,5)$
X

Skjoett Larsen

(2000, 114)
X

standard solutions to the client requirements" and integrated service agreement in which "the provider offers to take over the whole or large parts of the logistics process, including management and control of logistics activities, facility management and personnel administration"

"Activities carried out by a logistics service provider on behalf of a shipper and consisting of at least management and execution of transportation and warehousing. In addition, other activities can be included [....]. Also, the contract is required to contain some management, analytical or design activities, and the length of the co-operation between shipper and provider to be at least one year, to distinguish third party logistics from traditional 'arm's length' sourcing of transportation and/or warehousing."

"A relationship between a shipper and third party, which, compared with basic services, has more customized offerings, encompasses a broader number of service functions and is characterized by a longer term, more mutually beneficial relationship."

"Using the services of an external supplier to perform some or all of a firm's logistics functions. In principle, 'logistics' suggests a combination of two or more services, such as finished goods warehousing and outboundto-customer transportation. To be consistent with most interpretations of the term, ideally the activities should Sink and Langley $(1997,170)$

be conducted in an integrated or coordinated manner". 
"A close and long-term relationship between a customer and a provider encompassing the delivery of a wide

array of logistics needs. In a logistics alliance, the parties ideally consider each other as partners. They

collaborate in understanding and defining the customer's logistics needs. Both partners participate in designing

and developing logistics solutions and measuring performance. The goal of the relationship is to develop a win-

win arrangement."

"The use of external companies to perform logistics functions that have traditionally been performed within an

organization. The functions performed by the third party can encompass the entire logistics process or selected activities within that process."

Table 2. Some examples of 3PL definitions/interpretations, classified in chronological order based on their nature (i.e. 'inclusive versus 'exclusive') as per Knemeyer and Murphy (2005). 


\begin{tabular}{|c|c|c|c|c|c|}
\hline \multirow[b]{2}{*}{$\begin{array}{l}\text { Competitive advantages } \\
\text { required from logistics } \\
\text { outsourcing }\end{array}$} & \multicolumn{3}{|c|}{ Average importance } & \multirow[b]{2}{*}{$\mathbf{z}$} & \multirow[b]{2}{*}{$\mathbf{P}>|\mathbf{z}|$} \\
\hline & $\begin{array}{r}\text { Total } \\
\text { sample }\end{array}$ & $\begin{array}{c}\text { Strategic } \\
\text { outsourcing } \\
\text { sample }\end{array}$ & $\begin{array}{c}\text { Tactical } \\
\text { outsourcing } \\
\text { sample }\end{array}$ & & \\
\hline Operating cost reduction & $28.6 \%$ & $24.9 \%$ & $30.9 \%$ & 1.381 & 0.1673 \\
\hline Flexibility increase & $27.3 \%$ & $23.6 \%$ & $30.6 \%$ & 1.990 & 0.0465 \\
\hline Invested capital reduction & $17.1 \%$ & $17.7 \%$ & $16.6 \%$ & -0.195 & 0.8450 \\
\hline $\begin{array}{l}\text { Customer service level } \\
\text { improvement }\end{array}$ & $11.7 \%$ & $15.7 \%$ & $8.1 \%$ & -3.267 & 0.0011 \\
\hline $\begin{array}{l}\text { Risk reduction linked to the } \\
\text { development of knowledge and } \\
\text { new technologies }\end{array}$ & $9.0 \%$ & $9.4 \%$ & $8.7 \%$ & -0.951 & 0.3416 \\
\hline $\begin{array}{l}\text { Innovation capability } \\
\text { improvement }\end{array}$ & $6.4 \%$ & $7.7 \%$ & $5.1 \%$ & -2.077 & 0.0378 \\
\hline
\end{tabular}

Table 3. Average importance assigned to competitive advantages required from logistics outsourcing: Mann Whitney U test (p-values under which the null hypothesis is rejected are reported in bold, with a significance level of 5\%). 


\begin{tabular}{|c|c|c|c|c|c|}
\hline \multirow[t]{2}{*}{ 3PL selection criteria } & \multicolumn{3}{|c|}{$\begin{array}{l}\text { Average importance } \\
\text { (scale from } 1 \text { to 10) }\end{array}$} & \multirow{2}{*}{$\mathbf{z}$} & \multirow{2}{*}{$\mathbf{P}>|\mathbf{z}|$} \\
\hline & $\begin{array}{c}\text { Total } \\
\text { sample }\end{array}$ & $\begin{array}{c}\text { Strategic outsourcing } \\
\text { sample }\end{array}$ & $\begin{array}{c}\text { Tactical outsourcing } \\
\text { sample }\end{array}$ & & \\
\hline Flexibility in operations and delivery & 4.1 & 3.9 & 4.4 & 0.906 & 0.3647 \\
\hline Investment capacity & 4.3 & 4.4 & 4.0 & -0.450 & 0.6528 \\
\hline Operational performance & 4.3 & 4.5 & 4.1 & -0.044 & 0.9651 \\
\hline Market knowledge / Business experience & 4.4 & 3.7 & 5.1 & 1.946 & 0.0517 \\
\hline Long term relationship & 4.4 & 4.2 & 4.6 & 0.565 & 0.5722 \\
\hline Surge capacity & 4.4 & 4.4 & 4.4 & 0.307 & 0.7585 \\
\hline Broad range of service & 4.8 & 4.5 & 5.1 & 0.467 & 0.6403 \\
\hline Geographical spread & 4.9 & 4.0 & 6.0 & 2.289 & 0.0221 \\
\hline Information technology capability & 5.0 & 4.4 & 5.6 & 1.690 & 0.0910 \\
\hline Size and quality of fixed assets & 5.0 & 4.1 & 6.1 & 2.220 & 0.0264 \\
\hline Service level customisation & 5.0 & 4.9 & 5.1 & 0.713 & 0.4761 \\
\hline Financial stability & 5.0 & 4.7 & 5.4 & 0.385 & 0.7001 \\
\hline Quality of management & 5.0 & 4.5 & 5.4 & 1.168 & 0.2426 \\
\hline Control level of sub-contractors & 5.1 & 4.7 & 5.6 & 0.903 & 0.3666 \\
\hline High and improving standards & 5.2 & 5.0 & 5.6 & 0.554 & 0.5799 \\
\hline Employee satisfaction level & 5.3 & 4.8 & 5.8 & 0.858 & 0.391 \\
\hline Flexibility in billing and payment & 5.5 & 5.6 & 5.4 & -0.454 & 0.6501 \\
\hline Provider certification & 5.5 & 5.1 & 6.1 & 1.092 & 0.275 \\
\hline
\end{tabular}




\begin{tabular}{|c|c|c|c|c|c|}
\hline Tracking and tracing of the deliveries & 5.7 & 5.2 & 6.3 & 1.201 & 0.2296 \\
\hline Information sharing and trust & 5.8 & 4.8 & 6.7 & 2.332 & 0.0197 \\
\hline Attention to environmental sustainability & 5.9 & 5.8 & 6.2 & 0.370 & 0.7115 \\
\hline Reputation & 6.1 & 4.9 & 7.2 & 2.314 & 0.0207 \\
\hline Clause for arbitration and escape & 6.5 & 6.4 & 6.7 & 0.211 & 0.8332 \\
\hline Willingness to use shipper's logistics manpower & 6.5 & 7.1 & 5.8 & -1.347 & 0.1779 \\
\hline
\end{tabular}

Table 4. Average importance assigned to the 3PL selection criteria: Mann Whitney U test. (p-values under which the null hypothesis is rejected are reported in bold, with a significance level of 5\%). Note that the sample size varies according to each row of the table, as respondents only selected ten criteria out of 24. 


\section{List of Figures:}

Figure 1. Research background: classification of 3PL models.

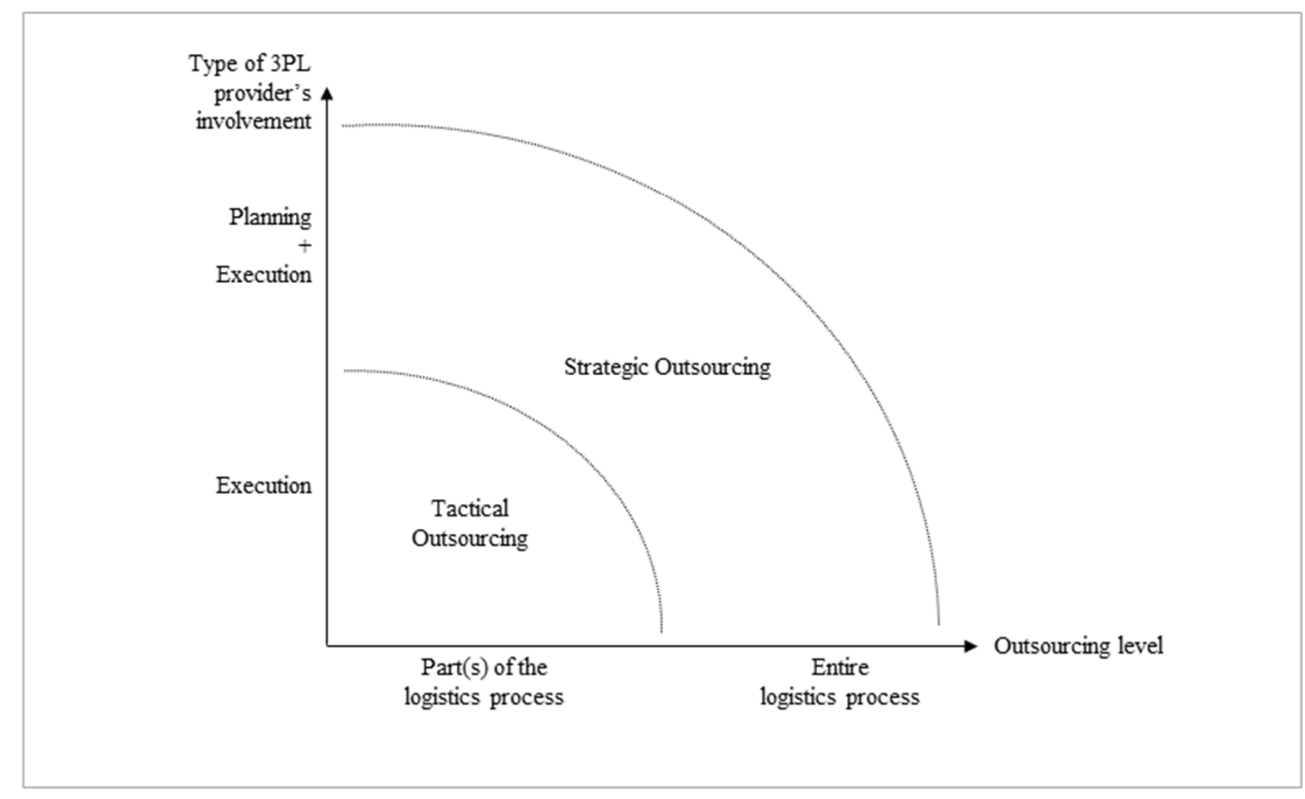

